\title{
Retraction Note to: Adaptive neuro-fuzzy selection of the optimal parameters of protective spur dike
}

\author{
Hossein Basser ${ }^{1}$. Shahaboddin Shamshirband ${ }^{2} \cdot$ Hojat Karami ${ }^{3}$. Dalibor Petković ${ }^{4}$. \\ Shatirah Akib ${ }^{1}$. Afshin Jahangirzadeh ${ }^{1}$
}

Published online: 28 May 2020

(c) Springer Nature B.V. 2020

\section{Retraction to: Nat Hazards (2014) 73:1393-1404 https://doi.org/10.1007/s11069-014-1140-5}

The Editors-in-Chief have retracted this article [1] because validity of the content of this article cannot be verified. This article showed evidence of substantial text overlap (most notably with the articles cited [2-6]), peer review and authorship manipulation. Hossein Basser does not agree to this retraction. None of the other authors responded to correspondence about this retraction.

\section{References}

1. Basser H, Shamshirband S, Karami H et al (2014) Nat Hazards 73:1393. https://doi.org/10.1007/s1106 9-014-1140-5

2. Basser H, Shamshirband S, Petković D et al (2014) Nat Hazards 73:1439. https://doi.org/10.1007/ s11069-014-1145-0

3. Petković D, Ab Hamid SH, Ćojbašić Ž et al (2014) Nat Hazards 74:463. https://doi.org/10.1007/s1106 9-014-1189-1

4. Petković D, Shamshirband S, Pavlovic ND et al (2014) Adv Eng Softw 77:28. https://doi.org/10.1016/j. advengsoft.2014.07.007

This article has been retracted. Please see the retraction notice for more details: https://doi.org/10.1007/ s11069-020-03923-y.

The original article can be found online at https://doi.org/10.1007/s11069-014-1140-5.

Shahaboddin Shamshirband

shamshirband1396@gmail.com

1 Department of Civil Engineering, University of Malaya, 50603 Kuala Lumpur, Malaysia

2 Department of Computer System and Technology, Faculty of Computer Science and Information Technology, University of Malaya, Kuala Lumpur, Malaysia

3 Department of Civil Engineering, Semnan University, Semnan, Iran

4 Department for Mechatronics and Control, Faculty of Mechanical Engineering, University of Nis $\ddot{y}$, Aleksandra Medvedeva 14, 18000 Nis, Serbia 
5. Petković D, Ćojbašić Ž, Lukic S (2013) Expert Syst Appl 40:4490. https://doi.org/10.1016/j. eswa.2013.01.055

6. Petković D, Ćojbašić Ž, Nikolić V (2013) Renew Sustain Energy Rev 28:191. https://doi.org/10.1016/j. rser.2013.07.049

Publisher's Note Springer Nature remains neutral with regard to jurisdictional claims in published maps and institutional affiliations. 